\title{
Overlapping Phenotypic Features of PTEN Hamartoma Tumor Syndrome and Birt-Hogg-Dubé Syndrome
}

\author{
Divya Angra, MD; Misty G. Eleryan, MD, MS; Maria Sotomayor, MD
}

\section{PRACTICE POINTS}

- PTEN hamartoma tumor syndrome (PHTS) represents a spectrum of disorders caused by autosomaldominant germline mutations in PTEN.

- Our patient presented with phenotypic features of PHTS and Birt-Hogg-Dubé syndrome. Given that both syndromes cause alterations in mammalian target of rapamycin signaling, overlapping phenotypic features may be seen.

- Recognizing overlapping phenotypic features of these syndromes will allow for timely diagnosis and surveillance for malignancy.

\section{To the Editor:}

PTEN hamartoma tumor syndrome (PHTS) encompasses a spectrum of disorders that most commonly are caused by autosomal-dominant germline mutations in the phosphatase and tensin homolog, PTEN, tumor suppressor gene on chromosome 10q23. We describe a patient who presented with clinical features of PHTS and Birt-HoggDubé syndrome (BHDS). Because the genetic mutations associated with both PHTS and BHDS result in altered mammalian target of rapamycin (mTOR) signaling, patients may have overlapping phenotypic features.

A 51-year-old man with a history of multiple carcinomas presented for evaluation of flesh-colored papules on the cheeks, nose, tongue, and hands, in addition to numerous skin tags on the neck, axillae, and lower abdomen bilaterally. His medical history was notable for several nasal and gastrointestinal tract polyps, chromophobe renal cell carcinoma, cutaneous lipomas, atypical carcinoid syndrome of the right lung, and a multinodular thyroid. His family history was notable for small cell lung cancer in his father, breast cancer and pancreatic cancer in his maternal aunt, esophageal cancer in his maternal grandfather, and celiac disease in his daughter.

Clinical examination revealed flesh-colored, domeshaped papules measuring 1 to $2 \mathrm{~mm}$ in diameter on the nose and cheeks (Figure 1). He had hyperkeratotic papules on the dorsal fingers, consistent with acral keratoses. Additionally, multiple flesh-colored papules with a cobblestonelike appearance were noted on the oral mucosa (Figure 2). Other findings included pedunculated papules on the neck, axillae, and lower abdomen bilaterally, consistent with fibroepithelial polyps, as

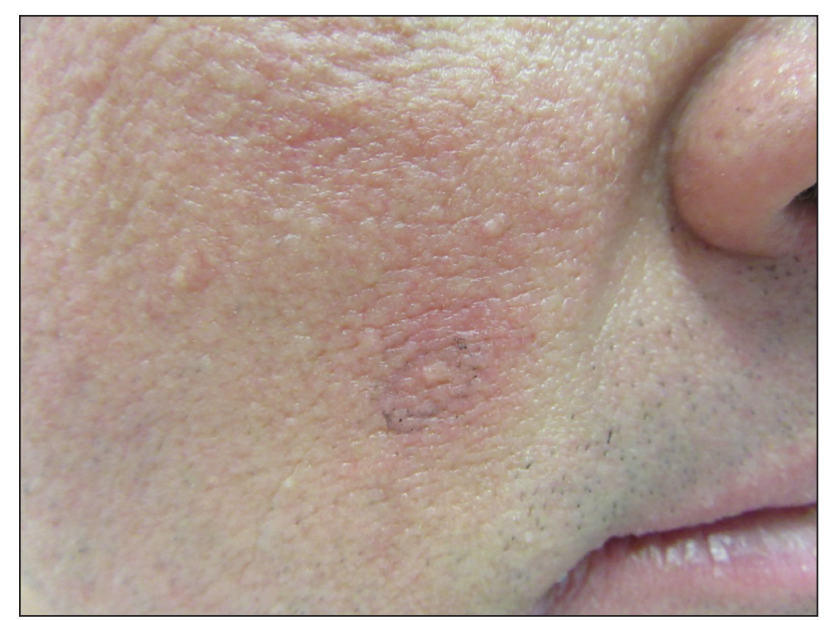

FIGURE 1. Flesh-colored papules on the right cheek with surrounding erythema.

Dr. Angra is in private practice, Alexandria, Virginia. Dr. Eleryan is from the Division of Dermatology, West Los Angeles VA Medical Center, UCLA David Geffen School of Medicine, California. Dr. Sotomayor is from Palm Harbor Dermatology, Tampa, Florida. 


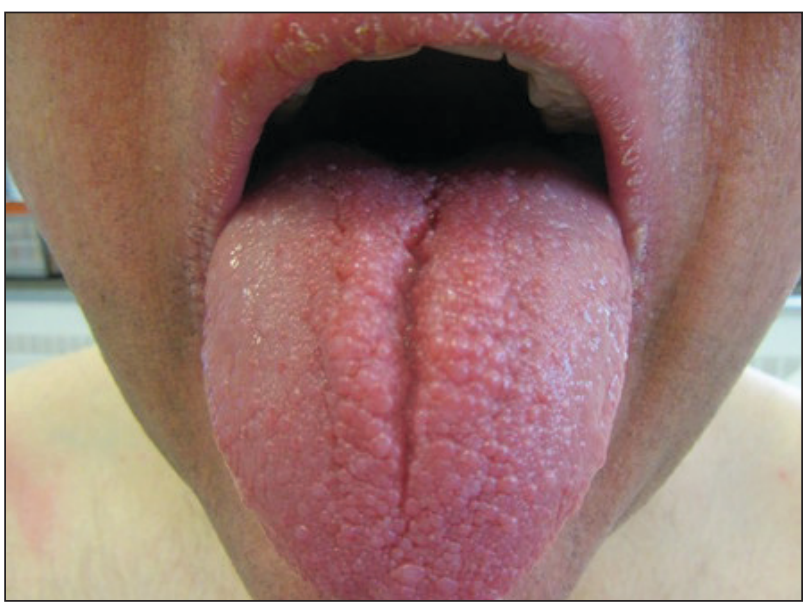

FIGURE 2. Multiple flesh-colored papules with a cobblestonelike appearance on the tongue.

well as hyperpigmented velvety plaques on the axillae, characteristic of acanthosis nigricans (Figure 3). A shave biopsy of a papule on the right cheek revealed a proliferation of plump stellate fibroblasts, small blood vessels, and thick collagen bundles, characteristic of a fibrous papule (Figure 4).

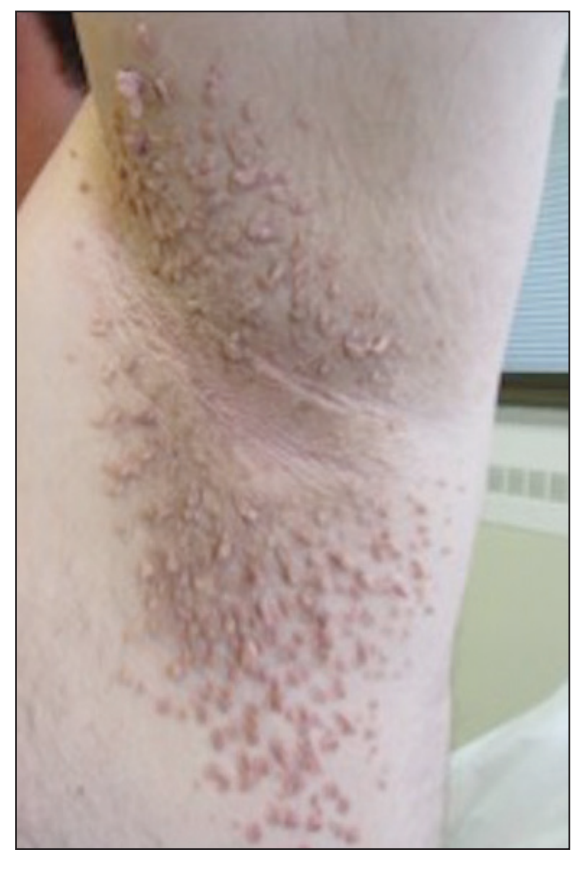

FIGURE 3. Several pink pedunculated papules on the left axilla. Hyperpigmented velvety plaques also were present, indicative of acanthosis nigricans.

\section{Description of Genetic Abnormalities, Clinical Manifestations, and Management of the PHTS Disorders}

\begin{tabular}{|c|c|c|c|}
\hline Syndrome & Gene involved & Clinical findings & Management \\
\hline Cowden syndrome ${ }^{1,2,4}$ & & $\begin{array}{l}\text { Mucocutaneous lesions; macrocephaly; } \\
\text { nonmedullary thyroid cancer, breast } \\
\text { cancer, endometrial cancer; multiple } \\
\text { gastrointestinal hamartomas or } \\
\text { ganglioneuromas; association with } \\
\text { Lhermitte-Duclos disease }\end{array}$ & $\begin{array}{l}\text { Regular surveillance and } \\
\text { comprehensive physical } \\
\text { examination; early detection of } \\
\text { malignant conditions; increased } \\
\text { breast and endometrial cancer } \\
\text { screening in women; thyroid } \\
\text { ultrasound, colonoscopy, renal } \\
\text { ultrasound; genetic counseling and } \\
\text { patient education }\end{array}$ \\
\hline $\begin{array}{l}\text { Bannayan-Riley-Ruvalcaba } \\
\text { syndrome } e^{1,3,5,6}\end{array}$ & PTEN & $\begin{array}{l}\text { Pediatric presentation; macrocephaly; } \\
\text { intestinal hamartomatous polyposis; } \\
\text { multiple thyroid nodules and tumors; } \\
\text { lipomas; pigmented macules of the } \\
\text { glans penis }\end{array}$ & $\begin{array}{l}\text { Similar surveillance as CS for } \\
\text { individuals with germline PTEN } \\
\text { pathogenic variants; monitor for } \\
\text { complications related to intestinal } \\
\text { hamartomatous polyposis }\end{array}$ \\
\hline Lhermitte-Duclos disease ${ }^{1,3,7}$ & PTEN & Dysplastic cerebellar gangliocytomas & Surgical resection \\
\hline Proteus syndrome $e^{1,3,6,8}$ & AKT1 & $\begin{array}{l}\text { Congenital malformations and } \\
\text { hamartomatous overgrowth of } \\
\text { tissues; connective tissue nevi; } \\
\text { epidermal nevi; hyperostosis }\end{array}$ & $\begin{array}{l}\text { Consider CS surveillance } \\
\text { recommendations for individuals with } \\
\text { germline PTEN pathogenic variants }\end{array}$ \\
\hline Proteus-like syndrome $e^{1,6,9}$ & PTEN & $\begin{array}{l}\text { Clinical features of Proteus syndrome } \\
\text { but failure to meet diagnostic criteria }\end{array}$ & $\begin{array}{l}\text { Consider CS surveillance } \\
\text { recommendations for individuals with } \\
\text { germline PTEN pathogenic variants }\end{array}$ \\
\hline
\end{tabular}

Abbreviations: PHTS, PTEN hamartoma tumor syndrome; CS, Cowden syndrome. 


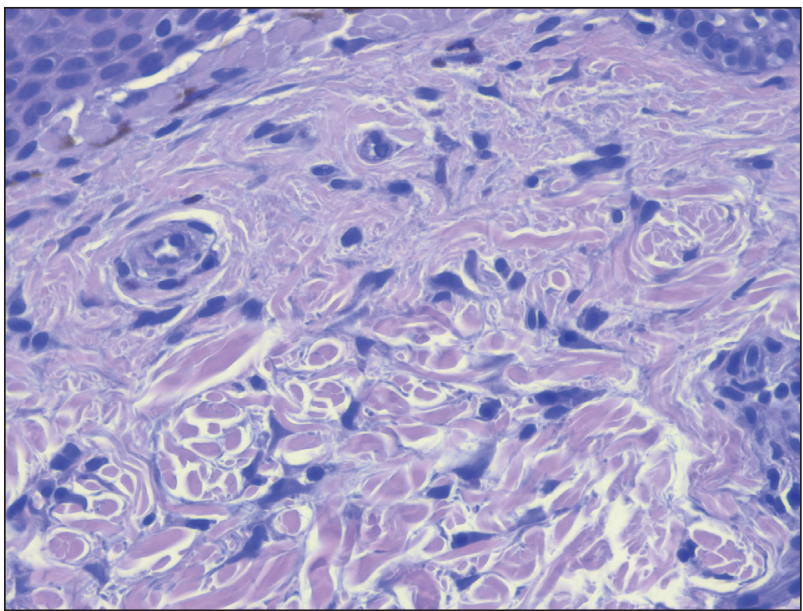

FIGURE 4. A histologic section of a biopsy of a facial papule showed a proliferation of plump stellate fibroblasts, small blood vessels, and thick collagen bundles $(H \& E$, original magnification $\times 20)$.

Differential diagnoses for our patient included BHDS and Cowden syndrome (CS). Due to the combination of extensive family history of multiorgan cancers as well as the clinical findings, he was referred to a geneticist for further evaluation. Genetic analysis was positive for a heterozygous mutation variant of uncertain significance in the PTEN gene.

The PHTS disorders include CS, Bannayan-RileyRuvalcaba syndrome, Lhermitte-Duclos disease, Proteus syndrome, and Proteus-like syndrome (Table). ${ }^{1-9}$ Our patient's clinical findings were indicative of $\mathrm{CS}$, a rare genodermatosis characterized by multiple hamartomas and neoplasms of ectodermal, mesodermal, and endodermal origin. ${ }^{1}$ Most CS patients develop trichilemmomas of the central face, mucocutaneous papillomatous papules, and acral and plantar keratoses by the third decade of life. ${ }^{1}$ Importantly, CS patients have an increased risk for breast, thyroid, renal, endometrial, and colorectal cancers, as well as melanoma, with estimated lifetime risks of $85 \%, 35 \%, 33 \%, 28 \%, 9 \%$, and $6 \%$, respectively. 2,10

Regarding the pathophysiology of PHTS disorders, PTEN encodes a phosphatase that inhibits phosphoinositide 3-kinase/Akt and mTOR signaling pathways, thereby controlling cell proliferation, cell-cycle progression, and apoptosis. ${ }^{2,3}$ Loss of PTEN function, as seen in CS patients, results in an increased risk for cancer. ${ }^{2}$ Other genetic diseases, including juvenile polyposis syndrome, Proteus syndrome, tuberous sclerosis, and Peutz-Jeghers syndrome, have phenotypic similarities to $\mathrm{PHTS}^{3}$ Specifically, loss-of-function mutations of TSC1 and TSC2, tumor suppressor genes associated with tuberous sclerosis, similarly result in dysregulation of $\mathrm{mTOR}$ signaling.
Our patient also had some clinical features characteristic of BHDS, such as flesh-colored facial papules, acrochordonlike lesions, and chromophobe renal cell carcinoma. ${ }^{11}$ Birt-Hogg-Dubé syndrome most often is caused by an autosomal-dominant germline mutation in FLCN, a tumor suppressor gene. ${ }^{11}$ Interestingly, FLCN interacts with AMP-activated protein kinase to help regulate $\mathrm{mTOR}$ signaling, which may explain phenotypic similarities seen in CS and BHDS. ${ }^{12}$

Because the PHTS disorders and BHDS result in similar functional consequences on the mTOR signaling pathway, patients can present with overlapping clinical features that may be diagnostically challenging. Management includes patient education regarding cancer risk, surveillance for early detection of malignancy, and genetic counseling for family members. ${ }^{2}$ It is important for clinicians to appreciate phenotypic similarities between PHTS and other disorders affecting mTOR signaling to prevent delays in diagnosis.

\section{REFERENCES}

1. Nosé V. Genodermatosis affecting the skin and mucosa of the head and neck: clinicopathologic, genetic, and molecular aspectPTEN-hamartoma tumor syndrome/Cowden syndrome. Head Neck Pathol. 2016;10:131-138.

2. Porto A, Roider E, Ruzicka T. Cowden syndrome: report of a case and brief review of literature. An Bras Dermatol. 2013;88(6 suppl 1):S52-S55.

3. Leslie $\mathrm{N}$, Longy M. Inherited PTEN mutations and the prediction of phenotype. Semin Cell Dev Biol. 2016;52:30-38.

4. The National Comprehensive Cancer Network (NCCN) clinical practice guidelines in oncology. genetic/familial highrisk assessment: breast and ovarian (version 1.2017). Published September 19, 2016. Accessed August 11, 2021. https://www.nccn.org /professionals/physician_gls/pdf/genetics_screening.pdf

5. Laury AR, Bongiovanni M, Tille J, et al. Thyroid pathology in PTEN-hamartoma tumor syndrome: characteristic findings of a distinct entity. Thyroid. 2011;21:135-144.

6. Eng C. PTEN hamartoma tumor syndrome. In: Pagon RA, Adam MP, Ardinger HH, et al, eds. GeneReviews. University of Washington; 2001.

7. Golden N, Tjokorda MGB, Sri M, et al. Management of unusual dysplastic gangliocytoma of the cerebellum (Lhermitte-Duclos disease) in a developing country: case report and review of the literature. Asian J Neurosurg. 2016;11:170.

8. Biesecker LG, Happle R, Mulliken JB, et al. Proteus syndrome: diagnostic criteria, differential diagnosis, and patient evaluation. Am J Med Genet. 1999;84:389-395.

9. Busa T, Milh M, Degardin N, et al. Clinical presentation of PTEN mutations in childhood in the absence of family history of Cowden syndrome. Eur J Paediatr Neurol. 2015;19:188-192.

10. Tan MH, Mester JL, Ngeow J, et al. Lifetime cancer risks in individuals with germline PTEN mutations. Clin Cancer Res. 2012;18:400-407.

11. Ponti G, Pellacani G, Seidenari S, et al. Cancer-associated genodermatoses: skin neoplasms as clues to hereditary tumor syndromes. Crit Rev Oncol Hematol. 2013;85:239-256.

12. Baba M, Hong S, Sharma N, et al. Folliculin encoded by the BHD gene interacts with a binding protein, FNIP1, and AMPK, and is involved in AMPK and mTOR signaling. Proc Natl Acad Sci U S A. 2006;103:15552-15557. 